Per cent.

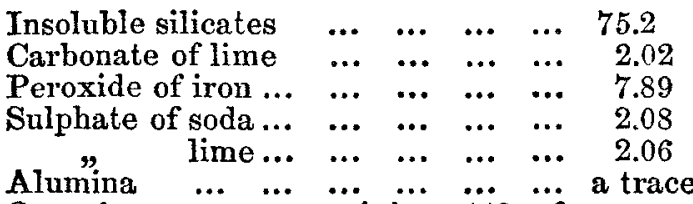

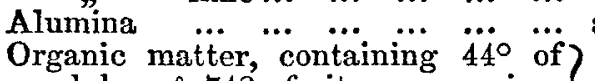

sulphur, \& 742 of nitrogen, equiva- $\{9.25$

lent to 902 of ammonia... ... ...

98.50

In the decomposition which the organic matter would undergo, in contact with atmospheric air and water, the sulphur above indicated would be converted into sulphuretted hydrogen, and other volatile sulphur compounds; and the nitrogen into ammonia, forming, at times, hydrosulphuret of ammonia, the product of privies and of cesspools."

The most important result of this analysis is the large proportion of sulphur contained in the organic matter of the water, and of the mud. This sulphur and nitrogen existed in the animal substances allowed to flow into that "part of the Ranelagh sewer commonly called the Serpentine," as it is justly termed by the Metropolitan Commissioners of Sewers. This sulphur also existed in the large beds of weeds which are permitted to extend their roots in the water, in search of some unfortunate bather whom they may entangle and drown.

The process of putrefaction having liberated the sulphur and nitrogen from the animal and vegetable substances with which they were combined, and under the influence of water and of atmospheric air, they unite with hydrogen, and form ammonia and sulphuretted hydrogen. You were therefore right in your assertion that sulphuretted hydrogen was generated in the mud of the Serpentine; that it forms one of the reasons of the offensive taste of the water; and that it is even sometimes exhaled from $i$ ts surface: and the medical correspondent of the Times was wrong in pretending that there was not more sulphuretted hydrogen to be found about the Serpentine than when you dip your spoon into that wellknown (and not to be despised) luxury, a fresh egg, which I hope you sometimes enjoy at your morning repast.

I remain, faithfully yours,

Gloucester-road, Hyde. park, Jan. 16, 1849.

Edward J. Tilt.

\section{THE COUNTRY SURGEON'S COMPANION.}

\section{To the Editor of The LancET.}

SIR,-I have just read, in a work of fiction called "Brampton Rectory, or the ILesson of Life," the enclosed beautiful description of the female companion of the hard-working country surgeon, and which may be met with in every goodsized village in the kingdom. The character is so well drawn, and so in accordance with real life, that $I$ could not help having it copied out, and sending it to you, thinking that you might find room for the whole or a part of it in some corner of your journal, where I think it would be read with interest.

Hastings, Jan. 1840 I am, dear Sir, yours sincerely,

" ' Is Mr. Locke a married man?' asked Basil.

" "No; but he has an excellent helpmate-a devoted sister. I wish you could see Sarah Locke in her own house. She is a plain, homely-looking person, with little talent but for practical things, and no pretensions to refinement, except that which is the natural product of an unselfish, feeling heart; but $I$ know few things in nature or art so beautiful as that moral loveliness which shines forth in characters like hers. Her devotion to her brother is complete, but even that is only a part and a consequence of her devotion to God. She said to me one day, 'I look upon my brother as having his appointed work to do in the world, and I look upon myself as being his appointed helper, and so I try all I can to make his work easy, to keep up his health and strength, and to cheer and comfort his heart; and the more I do this, I know the more and the better will he be able to do it for our Great Master.

" 'I have seen the wives of some professional men, who have apparently regarded their husband's calling as a sort of necessary evil-a means of getting money, and furnishing means for some other object, which to them is the chief good of life; and so I have seen them in manifest vexation, when the means perhaps encroach upon the end: annoyed, for instance, if their husbands are unable to go to a dinner party; or come in late; or if the calls of duty stand in the way of little schemes of pleasure and recreation; and sometimes they will even visit their displeasure on their husbands themselves; or perhaps they will grudge all charitable labours, and seem to regard them as a kind of injustice to family claims. But Sarah Locke has set before herself as her great end, the advancement of God's design for the benefit of His creatures. She knows that her brother is intrusted with a ' ministry of healing,' and in the fulfilment of that her heart is concentrated. She loves him with the tenderest affection, but she loves him as the servant of God. Of herself I believe she never thinks, but as something raised up and sustained for his sake. She arranges her small household entirely with a view to him. At whatever time he may come in, things are always ready for him; a neat and comfortable parlour, a cheerful fire, suitable refreshments, and, above all, a smiling affectionate face, and a ready sympathy. If, weary and worn out, he sits down to take a little sleep, she keeps everything quiet about him, and never allows him to be awoke without absolute necessity. If he wants to read or to think, she never teases him with questions, but sits by with her sewing in perfect silence. If he is disposed for a little recreation she lays by every occupation to read or to play at chess with him. I fancy she learnt the game entirely because she saw it was a solace to him. She gets up at all hours of the night to let him in, and to prepare for him a warm cup of coffee. She helps him to dispense his medicines, and all the spare time she has she devotes to visiting amongst his poor patients, and carrying out his directions by various little offices of kindness and assistance, for, to add to all her other qualities, she is, I feel persuaded from certain little specimens I have seen, one of the best and cleverest of nurses, and I wish for an assistant partly on this account, that she may be set free to perform a few more of these invaluable services." "

\section{THE QUACK ADVERTISEMENTS AND THE PUBLIC PRESS. \\ To the Editor of THE LANCET.}

SrR,-I venture again to address you on the evils of quacks and quackery. It is not sufficient in the present day that the pockets of the unfortunate dupes be drained, their health ruined, and their peace of mind destroyed-the cupidity of the trading periodical press must be fed, and public decency outraged by obscene advertisements appearing in the leading journals.

I am resolved to hold up to scorn and public execration every publication in which these abominable and filthy advertisements are permitted; and I ask, as the father of a family, if it be possible to permit the Morning Chronicle to be read by our wives and danghters, so long as advertisements such as the following are inserted. They all appear one after the other, in the Morning Chronicle of January 20, 1849.

The first work on the long list of bestiality is "Dr. Culverwell on Marriage, Infertility, and Divorce." "To be or not to be that is the question." "Subject-Marriage, its Intents and Obligations." "Numerous Illustrations of Marital Infelicities""

The second is "The Green Book," "On Morbid Secretions;" and the third, "Manhood; the Canses of its Premature Decay," This beastly work, "illustrated by engravings on steel, in colour, explaining the various functions, secretions, and structures of the reproductive organs," is "a medical essay on those diseases of the generative organs emanating from solitary habits," \&c., by J. L. Curtis, Consulting Surgeon.

The next is by Samuel La'Mert, M.D. It is adorned by "forty coloured engravings, illustrating the anatomy, physiology, and diseases of the reproductive organs," \&c. The last on the disgusting page of the Morning Chronicle of this day is "illustrated by forty coloured engravings on steel," "On Physical Disqualifications and Impediments to Marriage." "The Silent Friend, a medical work on the infirmities and decay of the generative system. By R. \& L. Perry \& Co., Consulting Surgeons." "Part the first treats of the anatomy and physiology of the reproductive organs, and is illustrated by six coloured engravings," \&c., and the whole concludes with a long list of medicines, described " as a certain remedy for gonorrhea, gleet, strictures," \&c.

Now, Sir, I ask if it be not disgraceful that in one number of such a leading and respectable journal as the Morning Chro. nicle, five advertisements of so indecent and abominable a character should be found? Is the editor of that paper at all aware of the nature of these publications, and of the system of extortion which may be pursued through the instrumentality of advertisements of this description-of the thousands who yearly become the victims of such practices? Can he reconcile it with the duty he owes to the public to permit advertisements of this disgusting and immoral character to appear? 